Richard Pfeilstetter

\title{
Anthropology and Social Work. Engagement with Humans, Moral Dilemmas and Theories of Difference
}

This is the pre-copyedited author's final version of the journal article accepted for publication following peer review.

Original citation:

Pfeilstetter, R. (2017). Anthropology and Social Work. Engagement with Humans, Moral Dilemmas and Theories of Difference. European Journal Of Social Work, 20 (2), 167-178.

The version of record is available online at:

https://doi.org/10.1080/13691457.2015.1131148 


\title{
Anthropology and Social Work.
}

\section{Engagement with Humans, Moral Dilemmas and Theories of Difference.}

\author{
Richard Pfeilstetter \\ Department of Social Anthropology, University of Seville, Spain \\ C/ Doña María de Padilla s/n \\ 41004 Sevilla (Spain) \\ (+34) 954554391 \\ rgp@us.es
}

This article compares similarities between two disciplines traditionally distinguished by applying a praxis-theory dichotomy. It is argued that this equally simple and historical opposition is reducing the current multiple realities of both fields in Europe inaccurately, as both disciplines have more in common than normally appreciated. Therefore the contribution compares the subjects 'culture' and 'social problem', showing some interesting overlaps in recent definitions. Furthermore, methodological parallels are traced in concepts such as participant observation, empathy or in-betweenness. In a third step, common roots in social theory and moral dilemmas of the past and the present for both social work and anthropology are discussed. Finally, the paper argues in favor of more collaboration, respectively, in practical training and academic research.

Keywords: Anthropology, Practice/theory/methods, Interdisciplinarity, Race/culture, Professions, Comparative approaches 


\section{Introduction $^{1}$}

In the UK and the US there is a long tradition of university-based training for social workers (Teicher 1951, p. 23-24) and a range of departments are shared by anthropology and social work in the US (for instance at the Universities of Seattle, Kansas State or Central Michigan). Also, in continental Europe, the recently implemented Bologna reform has led to new encounters between both disciplines at universities. For instance, in German-speaking countries, social work entered universities in the 1970s while Masters and $\mathrm{PhD}$ courses have been implemented, in collaboration with partners from other social sciences, more recently. Meanwhile, anthropologists' growing interest in the non-research labor market, for instance in Spain (Pfeilstetter 2015), is a result of the new obligation for undergraduate courses to ensure employability. This again is a consequence of the recent Bologna reform as part of a new "audit culture" at universities (Shore 2008). This will lead to new encounters both in academia and in the labor market. Of course experts in migration, poverty, gender, health or development from both fields have long been collaborating. Nonetheless, in this contribution I argue that both disciplines have more substantial parallels regarding their subjects, methods, theories and ethical self-understandings that are still to be explored.

I would like to make some preliminary considerations to forestall possible criticism that this text deliberately provokes and also some contextualizing comments on its genesis. The contribution tries to draw attention to similarities of two distinct disciplines, disciplines that are themselves more internally heterogeneous than presented here, for heuristic purposes, as confined entities. In doing so, the argument does not aim to undermine or criticize professionals in either field. Viewpoints included in this text may

\footnotetext{
${ }^{1}$ Email: rgp@us.es
} 
have resulted from my personal experience as a social worker trained in Germany, and as an anthropologist trained and exercising in Spain, and is possibly, therefore, more representative of certain national traditions or theoretical sensitivities than of others. Finally, some of the ideas of the paper were presented in a lecture at the 35 th Congress of the German Social Anthropological Association in 2013. Subsequently, the book "Ethnologie und Soziale Arbeit" (Ethnology and Social Work) has been edited by Magnus Treiber, Nicolas Grießmeier and Christian Heider (2015) and includes experiences of encounters beyond disciplinary frontiers from various professionals. Some of these contributions will back up my arguments empirically throughout the text, including my own on the institutionalized liaison of social work and anthropology in the case of Spain (Pfeilstetter 2015).

\section{Cultural diversity and social exclusion}

The classical definition of the subject in anthropology is the study of culture(s) while, normally, social work seeks answers to social problems. Although both disciplines have developed a large number of different definitions of their subject, some of which abandon classical terminologies, at least an allusion, in all outlines of the subject, to culture (Eriksen, 2010, p. 3-4) and social problems (Staub-Bernasconi, 1995, p. 105) normally still exists.

We may say that the anthropological subject is wider than the one engaged by social work as a discipline. Every social problem can be understood from a cultural point of view, but not every aspect of culture can be explained through social problem semantics. 
The subject [of social work], or that part of reality observed by social work is social problems [...] People suffer in and from society and culture (Staub-Bernasconi, 1995, p. 105 ; translation is mine)

Thus, culture is part of the problem of a social problem. Social work needs to consider culture as a key-factor both for the constitution and resolution of social problems. This emphasis on culture as a basic subject for social work research may be found in the definition of the International Foundation of Social Work:

Social work bases its methodology on a systematic body of evidence-based knowledge derived from research and practice evaluation, including local and indigenous knowledge specific to its context. (http://ifsw.org; my italics)

The reverse is also true. Culture does not necessarily have to be seen in terms of conflict, inequality or any other similar social problem semantic. Even so, there is quite a strong tradition, sometimes called critical anthropology, suggesting this (Nugent 2012). Such a vision of culture would favor a similar focus for both disciplines, namely the genesis and maintenance of difference (Litscher 2015, p. 89). The mutual theoretical point of departure then is the human practice of drawing distinctions, responsible both for cultural diversity and social inequality.

A second way of comparing culture and social problems as epistemological starting points for scientific activity could be by seeing the former as more objective than the latter. Social problems may already be interpreted as a social construction relative to time and space. The term problem may be seen as problematic theoretically because of its proximity to value judgments. In this sense, anthropologists who report on their collaboration with social workers hold that the latter already take for granted "problems" that should be left open to empirical examination. For instance, Maurus is reporting on preconceived definitions of "street children" in Addis Ababa (2015, p. 3637, 41), or Tauber on divergent perceptions of "corporal hygiene" between Sinti (an 
ethnic sub-group of the Romani population) and social workers in northern Italy (2015, p. 54). Already in the 1950s Teicher spoke of a donor-recipient relation between anthropology and social work in the U.S. where anthropology is the "teacher" that sees social work itself as a "cultural artifact", a "sub-culture [of] some parts of Westernsociety" (1951, p. 22). Half a century later not much seems to have changed. For instance, the above cited works from anthropologists also insist that social workers and their interventions are part of their subject of inquiry (Tauber 2015; Maurus 2015, p. 36) and that social workers would be well-advised to obtain some training on cultural diversity from anthropologists (Tauber 2015, p. 53). All these examples point to a basic problem in the relation between practitioners and researchers. The possibilities of improving practice, by revealing the unintended moral short-comings of social interventions, are reduced when these findings themselves are inadvertently communicated in moralizing-paternalistic terms. The expected reaction then is a critique of the theoretical-relativist approach (judging each culture on its own terms) which is not feasible in (social work) practice (Teicher 1951, p. 24).

In addition, "culture" as a concept is not free from moral connotations either, as by using the term the complexity of social life is reified into a unique identity, something "neat and tidy" as Eriksen asserts (2000, p. 4). Where the social worker is commissioned to find "social problems" the anthropologist traditionally was inclined to look for "cultures", that is, people sharing similar symbolic universes. Of course, the reification of the subject may be a common epistemological problem in social sciences as a whole. Furthermore, for every definition of a subject there is its critique. For instance, anthropologists were "writing against culture" (Abu-Lughod 1991), suggesting avoiding the word (Kuper 1999, p. x) and "get rid of it" (see overview in Eriksen 2000, p. 4). Nevertheless, it has also been argued that substituting culture with other concepts 
(such as ideology) or looking for ever more sophisticated definitions does not solve the problem either (Kuper 1999, p. x-xi). Finally, all the deconstructions of the subject need a point of departure. Thus, it seems to me that there is a quite similar dilemma here both for anthropologists and social workers. Looking again at Tauber's contribution might illustrate this argument. The category "corporal hygiene" was constituted through social work practice in order to isolate a "social problem". This allowed an anthropologist to observe the enactment of ideological (to avoid the word cultural) differences (between the social worker and their clients) and to write about a "culture" ("the Sinti") apparently under threat. Similar semantics are at work here, namely solving/treating social problems and safeguarding/reporting on cultural diversity.

The dilemma of recognizing social complexity while taking ethical positions (seriously) has shaped similar approaches in anthropology and social work. Both disciplines need to integrate a variety of knowledge about the human condition, avoiding excessive specialization.

In this sense Teicher held that

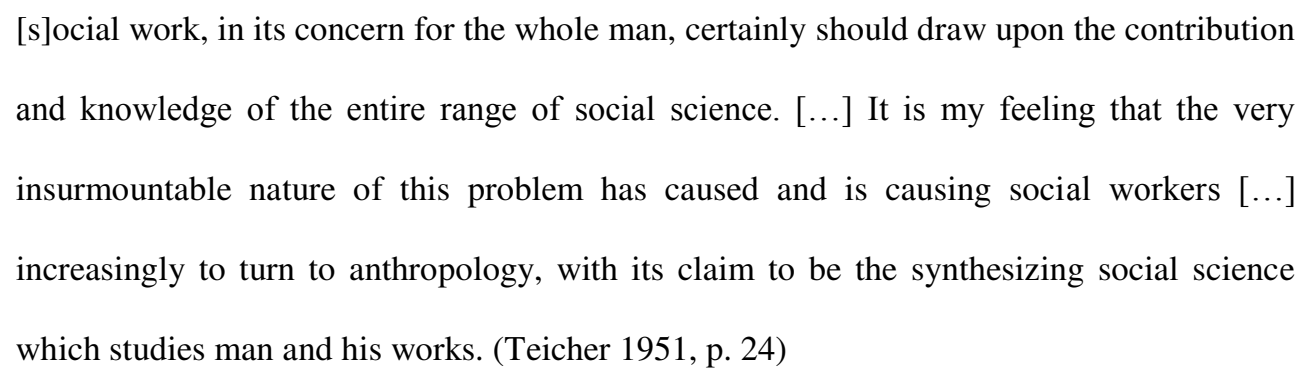

Most anthropologists consider that human reality can best be explained by taking into account, simultaneously, the psychological, social, biological, historical, geographic, linguistic, economic, political, religious, artistic dimensions of human reality. At the same time, anthropologists have argued that it is even difficult to make such distinction 
at all, for instance between the spheres of economy and kinship in traditional societies (Sahlins 1972). This holistic approach is sometimes used as a distinguishing feature of anthropology compared with economics, political sciences, law or sociology that were consolidated in the $19^{\text {th }}$ century as a consequence of abandoning integrative perspectives (Wolf 1982, p. 7 onwards). Here we may quote Eric Wolf, who argues in favor of the advantages of anthropology as a "bond between subject matters" and being "the most scientific of the humanities, the most humanist of sciences" $(1964$, p. 88).

Similar to this idea of holism is what social workers would call an interdisciplinary approach, or the employment of ancillary sciences.

[Social work] recognizes the complexity of interactions between human beings and their environment, and the capacity of people both to be affected by and to alter the multiple influences upon them including bio-psychosocial factors. The social work profession draws on theories of human development and behavior and social systems to analyze complex situations and to facilitate individual, organizational, social and cultural changes. (http://ifsw.org)

As evidenced, this potentially trans-disciplinary approach in both disciplines is not a recent academic fashion as may be the case with other disciplines. Both specialties subsequently describe their professional work frequently as translation, in anthropology, (Asad 1986, p. 142-143) and mediation, in social work. This position located in between disciplines or fields of knowledge, but also in between the people they work with on the one hand and the contracting authorities on the other, leads us to the question of the similarities in professional practices.

\section{Practicing science as direct engagement with humans}

Anthropology is widely associated with intensive ethnographic fieldwork, and as a discipline claims a singular methodological tradition rooted in the ground-breaking 
works of Franz Boas in the U.S. or Bronislaw Malinowski in Britain. This impetus is contested by other social sciences, such as sociology, which argue for their own ethnographic tradition (Giddens 1995, p. 274). Today "ethnography is an emergent interdisciplinary phenomenon" (Clifford 1986, p. 3) practiced also by social workers. As the following quote from Eriksen suggests, in practice it may be more a question of emphasis than of exclusivity:

Anthropology distinguishes itself from the other social sciences through the great emphasis placed on ethnographic fieldwork as the most important source of new knowledge about society and culture. (2010, p. 27)

Clifford's definition could give a hint as to why ethnography as a method is highly relevant for social work when he describes it as "telling the grounds of collective order and diversity, inclusion and exclusion.” (1986, p. 2). Grimshaw and Hart have argued that the rise of scientific fieldwork in anthropology in the $20^{\text {th }}$ century was inspired by a democratic impulse sympathetic to non-European cultures, rejecting evolutionist racism, demanding scientific respect for the mundane lives of ordinary people and attempting to abolish "the gap between the library and life" (1995, p. 49-51). The history of modern anthropology then could be portrayed as an awareness-taking-process in which participant observation, that is prolonged, direct and active engagement with people, leads to more accurate scientific insights into culture.

The evolution of social work as a profession and scientific discipline could be rendered inversely. The social organization of charity was the constitutive starting point for social work. Helping, educating or the supervising of people always meant becoming involved with them. Only later did the profession start to consider this from a scientific point of view, in terms of a professional method grounded on evidence-based knowledge. Ernst 
Engelke (1999) considers that these first steps of theorizing the intimate implication and interaction between humans emitting and receiving aid may be traced in, among others, the writings of Thomas Aquinas or Jean-Jacques Rousseau. Religious ethical canons are the first institutionalizations of charity as a socially organized and morally implemented set of social structures. Together with the different but complementary process of the Enlightenment, the emerging idea that humans are naturally equal and in need of education (Rousseau), make up the philosophical and historical foundation of social work. The scientific consolidation of social work practice comes into play once it starts to distinguish rationally organized aid and assistance from generic social human behavior of solidarity through kinship, neighborhood or faith. The emerging modern welfare state, a by-product of industrialization, is the midwife of the modern version of the discipline (as colonialism was for contemporary anthropology, a discussion that is going to be developed further on). In this process of rationalization of social assistance, social workers increasingly reflect on their personal involvement with clients in quite a similar way to the fieldworker. This may be shown by taking for instance Eriksen's definition of field work as a specific social process:

The very strength of ethnographic field method can also be its weakness: it is demanding, and rewarding, partly because the ethnographer invests not only professional skills in it, but also interpersonal skills. The ethnographer draws on his or her entire personality to a greater extent than any other scientist. For this reason, many emerge from the field exhausted, but with a material of extraordinary richness and depth. At the same time, this degree of personal involvement has important ethical implications. Are friendships and other confidential relationships developed in the field 'real' or 'fake'? What are the moral obligations of the ethnographer towards the informants? (Eriksen, 2010, p. 30-31)

If we reread this text, substituting the words field with work, ethnographer with social worker, and informant with client, we get a statement which social workers may accept as a precise description of the particularities of their own professional practice. This 
would also suggest that the differences in professional practices are more related to distinct professional vocabulary than of a substantive nature. The irony of Teicher's text when he explains the "language of this subculture" (social work) to the anthropological reader (the difference between case, group and community work) consists of showing that, despite the common ground he has argued for, there is no shared specialized lexis (1951, p. 22). It seems that there has not been much progress since then. For instance, Tauber's (2015) critique of assimilation policies regarding Sinti in Italy reveals typical eonfusion among anthropologists. On the one hand no big distinction is made between the state, public institutions, civil servants and social work and it is only agency that makes a difference. Yet, on the other, at times the suggestion is that social work needs to emancipate from the state, thus failing to recognize the double mandate constitutive for this profession.

As I want to argue onwards, once having a closer look at signifiers and signified in professional lexis at both ends some curious analogies can be found. A first example is the specific history of denominations of the people both disciplines engage with, namely their clients (social work) and informants (anthropology). One major term social workers have developed for the commitment to the people they deal with is empathy. For social workers, this term means a general professional attitude of positive interaction with the clients in order to enable an understanding of the socio-cultural and psychological circumstances that lead to subjective and/or objective social problems. In a very similar way to the notion of empathy, some anthropologists talk about rapport as the crucial precondition for fieldwork.

Rapport and empathy are semantically different, one being perhaps more focused on intellect, the other on emotion; fellowship, fellow feeling. Both, however, overlap as glosses for what ostensibly happens during the best, the most fruitful, and the most 
significant conversations that occur during that empirically messy activity our discipline continues to call ethnography. (Gable 2014, p. 241)

The role adopted by the anthropologist when they introduce themselves into a native society needs to avoid rejection by the host community. Therefore fieldwork is “profoundly personal [...] and most anthropologists probably feel a lifelong attachment to their first field site" (Eriksen, 2010, p. 31). Without a certain degree of sympathy between professionals and their clients/informants both social work and anthropological practice is simply impossible. Inversely, the professional attitude and the institutional mandate create distance and awkwardness. The conversion into a native/client is structurally impossible, scientifically undesirable and morally doubtful. However, admission by the community is a paramount requirement. Solidarity and complicity needs to be established through personal involvement. In addition, many social workers are also social service users at some stage and anthropologists do "fieldwork at home" studying their own societies. Therefore, both anthropologists and social workers have to balance these ambiguities and contradictions, between the private and the professional, between ethics and science, participation and distance, between the own biography and those of others. Meanwhile other social sciences, such as classic economics or statistical sociology, try to exclude the researcher from their subject of enquiry, both social work and anthropology build on subjectivity as a professional tool.

\section{Common roots in the history of social theory}

Looking for common heritage within the history of social theory, the first urban studies of the Chicago School are fundamental both for social work and anthropology (Treiber 2012; Litscher 2015, p. 76). In anthropology, the works of the Chicago School, and in particular of Robert Park, are often stated to be the first ethnographic approaches 
applied within western societies (Hannerz, 1986, p. 42). Those sociologists doing field work in the city during the first part of the $20^{\text {th }}$ century were increasingly cited by anthropologists as the distinction between exotic and familiar cultures itself became fragile and challenged.

Simultaneously, in social work, Jane Addams is, for some, regarded as the founding mother of social work theory (Engelke, 1999; Wendt, 1995, p. 156 onwards). Social work as active intervention within social settlements, as practiced at the Hull House by Addams, could be understood as the beginning of social community work. Both Addams and Park worked on common topics, at the same time and in the same city, and with similar methodological approaches. Both did participatory social research on the crumbling edges of Chicago's society at the beginning of the $20^{\text {th }}$ century. In 1910 Addams published "Twenty years at the Hull House" and five years later Park's "The City: Suggestions for the Study of Human Nature in the Urban Environment" came out. The titles of these publications already indicate what Ernst Engelke, quoting Silvia Staub-Bernasconi, refers to as two different scientific interests, that of Addams and the Chicago School. It is argued that scientific approaches contrast with applied orientations in both intellectual works (Staub-Bernasconi in Engelke, 1999, p. 148). The Chicago School was interested in the milieus of immigrants and minorities to explain the emergent modern urban life from a scientific point of view. They tried to experiment with new ways of empirical research at a time when sociology as an academic field of knowledge was emerging and consolidating itself institutionally at universities. At the same time, "the Chicago Sociology School is known to have used rich primary sources elaborated by social workers” (Malagón Bernal et al., 2008, p. 140). Jane Addams' investigations were always linked to her activism for improving the living conditions of poor people. Her work was driven by her political, civic and educational interests. Both 
researchers and activists worked on the negative social consequences of industrial, urban society, the starting point both for social work as a science and anthropology "at home". Engelke also questions the distinction between activists and scientists when he argues that the philanthropy of Addams is always a scientific philanthropy which emphasized the empirical foundation of social interventions (1999, p. 148). At the same time, the social commitment of some Chicago School members can be explained through their selection of topics, study methods and biographical backgrounds. Anderson's "Sociology of the Homeless Man" (1923) for instance, based on his experience as a member of the community he describes through participant observation, is perhaps the best example of the shared roots of social work and anthropological theory.

Looking at recent theoretical developments, I would like to argue that the specific postmodernist arguments in anthropology and social work, have substantially eroded the praxis-theory distinction by which both disciplines could traditionally be distinguished (social intervention as different to social science). This has led to a similar, though rarely appreciated, theoretical foundation of thoughts and actions in both disciplines. Among the most popular authors associated with deconstructivist ideas in anthropology was Clifford Geertz. In "Works and Lives: The anthropologist as an author" (1988) he disclosed the intimate relation between the social scientist and his subject. Although Geertz underlined that he did not want to delegitimize the classic writings of Malinowski, Benedict, Evans-Pritchard or Lévi-Strauss, he exposed anthropological knowledge as a construction of reality based on nothing more than text. It is still generally held that anthropologists have to underline the influence of the researchers' personality in the knowledge-obtaining process (Bourdieu and Wacquant 1995). Professionals discuss and assume the inherently different interpretations of their work. 
In the end, this paradigmatic shift challenged the universal validity of anthropological knowledge. It fostered a generalized consciousness that social science is always both altering social reality and interpreting it. In addition, the renewed cultural relativism, which was established by Franz Boas at the very beginning of cultural anthropology, shifted the focus away from giving universal answers to the perception of specific problems.

While the postmodern turn undermined classic scientific expertise, as produced by anthropology, it subsequently had an empowering potential for disciplines marginalized by traditional scientific hierarchies. This is the case with social workers in continental Europe, who historically suffered from being considered less-scientific, as their delayed entry into the universities, for example in Germany in the 1970's, in Spain in the 1980's, shows. At the end of the 1990's, Heiko Cleve spoke of social work as a postmodern science $(2000,2002)$. His contribution, influential in German speaking countries, argued that ambivalence is characteristic both for social work and postmodern societies. His work is an example of how the postmodern discourse has been adopted from social work to underline the strong points of applied sciences. Selective incorporation of knowledge from different disciplines by social workers is thus transformed from an arbitrary and eclectic unscientific practice into a core competence in postmodern scientific expertise.

Western logic and science is just one domain among various possible forms of human knowledge, or regimes of truth in Foucault's words (see Rabinow 1986, p. 237). This postmodern idea opened possibilities for intersections between practical and theoretical knowledge, between social practitioners and cultural analysts. Finally, it allows anthropologists and social workers to take the life worlds or the truths' of their clients 
and informants seriously, while simultaneously offering a distinctive, scientific knowledge to explain or change life in society.

\section{Moral dialectics and power relations}

Seen from a political-historical point of view, both disciplines have been related since their origins to the modern, bureaucratic nation state which assigns concrete functions to the professionals it maintains. This function for social work in liberal, democratic and market-based societies is to attend to the negative consequences for citizens of capitalism and modernization. Modernity produces a specific and systematic exclusion of certain groups unable to adapt themselves, for different reasons, to a social system based on competition and individual liberties. Functionally differentiated societies have developed (complementary to the old, still existing, systems of repression and surveillance) a new system based on public education, health care, social security, reinsertion and compensation, etc., of which social work is a part (Luhmann 1973). What social workers call their institutional mandate is nothing other than the fact that social work as an institution is part of these forces that produce social exclusion at the same time as being part of their solution. This paradox is an ethical dilemma at the very heart of institutionalized modern social work and today is part of its professional identity.

The original sin in the case of anthropology lies in its rise and proliferation in the west as a new discipline dealing with otherness in times of colonialism, racism, slavery and ethnocide. "[I]mperial and colonial power made access to 'anthropological societies' possible" (Nugent 2012, p. 8). For instance, anthropologists justified racial segregation during the Apartheid regime with the argument of maintaining cultural diversity (Kuper 1999, p. xiii). The idea of culture as a set of integrated and precisely defined practices, 
beliefs and ways of thinking, rooted in the German-romantic tradition, leads to identity politics justifying human segregation processes and power-relations using an anthropologically-informed knowledge of culture (Kuper 1999, p. 10). Today the debates on the political outcomes of (applied) anthropology can be seen as a direct consequence of European nations losing their colonies. Development policies are a specific form of colonialism for many anthropologists (see prominently Escobar 1997). Anthropology is still inherently a part of and an actor in the cultural system it attempts to analyze and this fact is, as with social work, a basic concern for anthropologists (Clifford 1986, p. 3). Therefore, as Geertz stated, “the anthropologist's severest term of moral abuse, [is someone being] ethnocentric" (1973, p. 24).

The rise of both disciplines is embedded in a historical process nowadays seen as immoral: the ethnocentric-western classification, and the administrative-political control of the others. The collaborations of ethnologists and caring professionals in the taxonomy and oppression of immigrants, foreigners, the indigenous, the disabled, the poor, the working class, just to name a few, led to specific ethical concerns and debates within both disciplines, some of which I will outline in the following.

While it was argued that “one of modern anthropology's durable, [ethical] contributions has been simply to disregard the idea that $[\ldots]$ one culture is intrinsically superior or inferior to any other." (Nugent 2012, p. 7) this cultural-relativistic stance can itself be seen as a specific ethical problem of the discipline leading, ultimately, to nihilism (Eriksen 2010, p. 8-9). When Malinowski's diaries were published in 1967, the xenophobic attitudes of anthropology's heroic ethnographer were exposed. Among others this led to the so called writing culture debate (Clifford and Marcus 1986; Geertz 1988) that challenged the political and biographical bias in anthropological writing. 
Since then ethical guidelines for ethnographic practice have been developed in major associations, for instance the code of ethics by American Anthropological Association in 1998 (aaanet.org), the ethical declaration by the German Anthropological Association in 2009 (dgv-net.de) or the ethical guidelines from the Association of Social Anthropologists of the UK and the Commonwealth in 2011 (theasa.org). Nevertheless, Lambek has argued, that ethics as a field of empirical research has been reduced in anthropology, to its "intellectualized, materialized, or transcendentalized" form in values, worldviews, law or religion, and not so much in its ordinary form as a basic condition of human life (2010, p. 1-6).

Anthropologists and social workers earn their living by participating in the lives of others. Social workers try to change; anthropologists want to inform on the lives of others. As I argued before, changing the lives of others always implies, to a certain degree, telling their lives. Conversely, studying the circumstances of people through active engagement leads, even if involuntarily, to social change. Social relations and everyday life are essential to their research and practice. In this context, moralities are both the subject of inquiry and guidelines for acting. At the same time, moral arguments justify the existence of anthropology and social work. Cultural diversity, as promoted for instance by UNESCO, is a common value within western societies and anthropology is perceived at times as an advocate of its safekeeping. The same occurs with charity or social justice in relation to social work. Silvia Staub Bernasconi, for example, argues that social work should be both recognized and defended as a Human Rights Profession (1995). The same way as I traced a common, morally questionable, historic origin in both disciplines, there exists a complementary, more optimistic, vision of present and past. Social work would then be the institutionalization of social justice, defending the weak, and anthropology the institutionalization of tolerance, defending minorities. The 
counterpart to this positive moral dialectic is a suspected unprofitability and potential superfluousness of anthropology and social work as scientific disciplines.

This leads us from the power-relations within and outside the disciplines to the powerrelations between the disciplines. These relations are determined by imperative shared values in a given society which scientific systems are part of. In the field of science as a whole, social and human sciences occupy a generally weak position, both in a material and idealistic sense. But in this field there also exists a hierarchy among disciplines both in a qualitative and a quantitative sense. Anthropology and social work have always occupied an inferior position in relation to law, economics, sociology, pedagogy, psychology or philosophy. Quantitatively, anthropology has been "smaller" than these; qualitatively, social work has been scientifically inferior to these. Others have had stronger professional lobbies, a wider impact on the labor market, a clearer profile within the media, and a better understanding in society of their contents and functions. This border line position of social work and anthropology can be observed in the history of science and universities. Social work and anthropology had to fight for their recognition as independent disciplines. Even today, students in both disciplines spend a lot of their time learning what actually makes the difference between their field of knowledge and others. This was my experience both studying social work in Germany (why it is an independent science) and anthropology in Spain (what makes it different to sociology). Today, anthropology and social work are still the object of attacks on their respective professional independence. In 2007 for example, the Organisation for Economic Cooperation and Development (OCDE), published the Revised Field of Science and Technology Classification where Anthropology is categorized as a subfield of Sociology. The president of the European Association of Anthropologists wrote a letter claiming that the 
inaccurate location of this field of knowledge, $[\ldots]$ misrepresents both the history and the current standing of Anthropology as a Social Science in itself, along with other Social Sciences

The director for science, technology and industry of the OCDE replied to the letter of the EASA president stating that "it is unlikely that Anthropology (and Ethnology) will appear as a separate social science for reasons of historical comparability and the need for concision" (both letters were published in the EASA newsletter no. 52 in December 2010).

\section{Conclusions and practical outlook}

Similarities in subjects, methods, theories, practices, and a common, generally, weak position inside and outside academia in continental Europe, leads me finally to defend the fruitfulness and opportunity of a more extensive collaboration between social workers and anthropologists at a university level not only related to some common areas of professional interest such as migration or health.

\footnotetext{
Interdisciplinary work, so much discussed these days, is not about confronting already constituted disciplines (none of which, in fact, is willing to let itself go). To do something interdisciplinary, it's not enough to choose a "subject" (a theme) and gather around it two or three sciences. Interdisciplinarity consists in creating a new object that belongs to no one. (Barthes cited in Clifford 1986, p. 1)
}

The most interesting field for the exchange between social work and anthropology is between scientific-theoretical and professional-applied knowledge. Social work as a discipline has a highly developed system of practical training at a university level. Its huge presence in the labor market, in many fields potentially occupied by anthropologists, is not the only explanation for this. Nevertheless, social workers' experience with qualifying their students for research, and offering $\mathrm{PhD}$ courses is 
relatively new for instance in German speaking countries. In Germany and Austria, social work situated at universities of applied sciences is forced to establish collaborations with disciplines traditionally monopolizing the right to grant $\mathrm{PhD}$ degrees. While the Alice Salomon University in Berlin tried to look for alliances in countries were social work as a discipline has the right to grant $\mathrm{PhD}$ degrees (UK, Finland and Slovenia, see the INDOSOW international $\mathrm{PhD}$ program), the Catholic University of Applied Sciences in Munich started a joint venture with the fields of psychology and education at the University of Munich (LMU). Anthropology does not seem to be considered as a potential partner in this respect.

In Spain, the Bologna process posed a challenge for anthropology departments to deal satisfactorily with novel requirements for practical training and internships (Pfeilstetter, 2012). The newly established undergraduate programs in anthropology now face demands of employability of students and teaching of practical skills. At the University of Seville and other departments in Spain, this concern has been addressed by inviting lecturers from different social sciences (social psychology, history, sociology, politics, etc.) into their undergraduate courses. The benefits from more sophisticated practical training for their students from social work professionals have not been considered as an option. These two examples from Spain and Germany may apply in a similar way to other European institutional settings.

The Bologna reform could still be the starting point for this type of mutually beneficial collaboration, leaving old perceptions of both disciplines behind and focusing on the new, similar but not identical realities of what social workers and anthropologists do. As Clifford Geertz once stated: 
$[\ldots]$ if you want to understand what a science is, you should look in the first instance not at its theories or its findings, and certainly not at what its apologists say about it; you should look at what the practitioners of it do (1973, p. 5).

\section{References}

Abu-Lughod, L. (1991) Writing Against Culture. In: Richard Fox (Ed.) Recapturing Anthropology: Working in the Present. (pp. 137-62) Santa Fe, NM: School of American Research Press.

Addams, J. (1912). Twenty Years at Hull-House. New York: MacMillan Company.

Anderson, N. (1961). [1912]. The Hobo: The Sociology of the Homeless. Chicago: University of Chicago Press.

Asad, T. (1986). The Concept of Cultural Translation in British Social Anthropology. In: Clifford, James \& George E. Marcus (Eds.). Writing Culture: The Poetics and Politics of Ethnography. (pp. 141-164) Berkeley, CA: University of California Press.

Bourdieu, P. \& Wacquant, L. (1995). Respuestas. Por una antropología reflexiva. México D.F.: Grijalbo.

Clifford, J. G. \& Marcus, E. (1986), Writing Culture: The Poetics and Politics of Ethnography. Berkeley, CA: University of California Press.

Clifford, J.G. (1986). Introduction: Partial Truths. In: Clifford, James \& George E. Marcus (Eds.). Writing Culture: The Poetics and Politics of Ethnography. (pp. 1-26) Berkeley, CA: University of California Press.

Engelke, E. (1999). Theorien der Sozialen Arbeit. Eine Einführung. Freiburg: Lambertus.

Eriksen, T. H. (2010). Small Places, Large Issues: An Introduction to Social and Cultural Anthropology. London: Pluto Press. 
Escobar, A. (1997). Anthropology and Development. International Social Science Journal, 49 (154), 497-515.

European Association of Social Anthropologists. (2010). EASA-newsletter number 52. Retrieved from www.easaonline.org/downloads/newsletters/easa_news_52.pdf_(accessed 12 October 2013).

Gable, E. (2014). The Anthropology of Guilt and Rapport: Moral Mutuality in Ethnographic Fieldwork. HAU: Journal of Ethnographic Theory, 4 (1), 237-58.

García Canclini, N. (1999). Los usos sociales del Patrimonio Cultural. In E. Aguilar (Ed.), Patrimenio Enológico. Nuevas perspectivas de estudio (pp. 16-33). Sevilla: Junta de Andalucía,.

Geertz, C. (1973). The Interpretation of Cultures: Selected Essays. New York: Basic Books.

Geertz, C. (1988). Works and Lives: The Anthropologist as Author. Stanford: Stanford University Press.

Giddens, A. (1995). Epilogue: Notes on the Future of Anthropology. In: A. Ahmed \& C. Shore (Eds). The Future of Anthropology: Its Relevance to the Contemporary World. (pp. 272-277). London: Athlone Press.

Grimshaw, A \& Hart, K. (1995). The Rise and Fall of Scientific Ethnography. In: A. Ahmed \& C. Shore (Eds). The Future of Anthropology: Its Relevance to the Contemporary World. (pp. 46-64). London: Athlone Press.

Hannerz, U. (1986). Exploración de la Ciudad: Hacia una Antropología Urbana. México D.F.: Fondo de Cultura Económica.

International Federation of Social Workers. (2012). Definition of Social Work. Available at: ifsw.org/policies/definition-of-social-work (accessed 22 December 2013). 
Kleve, H. (2000) Die Sozialarbeit ohne Eigenschaften. Fragmente einer postmodernen Professions- und Wissenschaftstheorie Sozialer Arbeit. Freiburg: Lambertus.

Kleve, H. (2002) Die postmoderne Theorie Sozialer Arbeit. Ein möglicher Blick auf die real- und theorie-historische Entwicklung der Sozialarbeit/Sozialpädagogik. Das gepfefferte Ferkel. Online-Journal für systemisches Denken und Handeln September 2002. Retrieved from www.ibs-networld.de/ferkel/sept-kleve.shtml (accessed 12 December 2013).

Kuper, A. (1999) Culture. The Anthropologists’ Account. Cambridge: Harvard University Press.

Lambek, M. (2010) Introduction. In: Lambek, M. (ed.) Ordinary Ethics: Anthropology, Language and Action. (pp. 1-36). New York: Fordham University Press.

Litscher, M. (2015). Vielfalt und städtische Entwicklungs- und Planungsprozesse: Forschen, mitreden, eingreifen. In: Treiber, M., Grießmeier N. \& Heider H. (Eds), Ethnologie und Soziale Arbeit. Fremde Disziplinen, gemeinsame Fragen? (pp. 73-92) Opladen: Budrich UniPress.

Luhmann, N. (1973). Formen des Helfens im Wandel gesellschaftlicher Bedingungen. In H. U. Otto \& S. Schneider (Eds.), Gesellschaftliche Perspektiven der Sozialen Arbeit. Erster Halbband. (pp. 21-43). Neuwied: Luchterhand.

Malagón, J. L., Sarasola Sánchez-Serrano, J. L. \& Barrera, E. (2008). Social Work: Progress or Backward Movement? In G. J. Friesenhahn, V. Fortunato \& E. Kantowicz (Eds.), Social Work in Restructured European Welfare Systems. (pp. 139-150). Roma: Carocci.

Malinowski, B. (1989). [1967]. A Diary in the Strict Sense of the Term. Stanford: Stanford University Press.

Maurus, S. (2015). Straßenkinder in Addis Ababa, Äthiopien - Eine interdisziplinäre Forschung. In: Treiber, M., Grießmeier N. \& Heider H. (Eds), Ethnologie und 
Soziale Arbeit. Fremde Disziplinen, gemeinsame Fragen? (pp. 165-180)

Opladen: Budrich UniPress.

Nugent, S. (Ed.) (2012). Critical Anthropology: foundational works. Walnut Creek: Left Coast Press.

Organisation for Economic Cooperation and Development. (2006). Revised field of science and technology (FOS) classification in the Frascatimanual. Retrieved from www.oecd.org/dataoecd/36/44/38235147.pdf (accessed 18 November 2013).

Park, R. \& Burgess, E. (1925). The City: Suggestions for the Study of Human Nature in the Urban Environment. Chicago: University of Chicago Press

Pfeilstetter, R. (2012). Innovación docente en el marco del Plan Bolonia. Un análisis de casos. In: I Congreso Virtual Internacional sobre Innovación Pedagógica y Praxis Educativa: INNOVAGOGÍA, Sevilla, Spain, 21-23 November 2012, pp. 628-634. Sevilla: AFOE.

Pfeilstetter, R. (2015). Ethnologie und Soziale Arbeit. Über die Vorteile einer Zusammenarbeit für zwei periphere Disziplinen am Beispiel Spanien. In: Treiber, M., Grießmeier N. \& Heider H. (Eds), Ethnologie und Soziale Arbeit. Fremde Disziplinen, gemeinsame Fragen? (pp. 165-180) Opladen: Budrich UniPress.

Rabinow, P. (1986). Representations are Social Facts: Modernity and PostModernity in Anthropology. In: Clifford, James \& George E. Marcus (Eds.). Writing Culture: The Poetics and Politics of Ethnography. (pp. 234-261) Berkeley, CA: University of California Press.

Sahlins, M. (1972). Stone Age Economics. New York: de Gruyter.

Shore, C. (2008). Audit Culture and Illiberal Governance. Universities and the politics of accountability. Anthropological Theory 8 (3), 278-298.

Staub-Bernasconi, S. (1995). Das fachliche Selbstverständnis Sozialer Arbeit - Wege aus der Bescheidenheit: Soziale Arbeit als Human Rights Profession. In W. R. 
Wendt (Ed.), Soziale Arbeit im Wandel ihres Selbstverständnisses: Beruf und Identität (pp. 57-104). Freiburg: Lambertus.

Staub-Bernasconi, S. (1995). Systemtheorie, soziale Probleme und Soziale Arbeit: lokal, national, international. Oder: Vom Ende der Bescheidenheit. Bern: Haupt.

Staub-Bernasconi, S. (2012). Zur Struktur der Wissenschaft der Sozialen Arbeit Wieder rückwärts zum Anfang oder ein paar Schritte nach vorn? In: Fachbereichstag Evangelische Hochschule Soziale Arbeit „Einmischen und Verändern? - Wissenschaft der Sozialen Arbeit in der Verantwortung “, Dresden, Germany, 22-24 May 2012.

Tauber, E. (2015). Soziale Arbeit und Ethnologie in der Politikgestaltung mit Sinti. In: Treiber, M., Grießmeier N. \& Heider H. (Eds), Ethnologie und Soziale Arbeit. Fremde Disziplinen, gemeinsame Fragen? (pp. 49-71) Opladen: Budrich UniPress.

Teicher, M. (1951). Anthropology and Social Work. Human Organization, 10 (3), 22-24.

Treiber, M. (2012). Ethnologie als Bezugswissenschaft der Sozialen Arbeit. Über Kartographie, Freiraum und das Unmittelbare in Stadt und Welt. In: Tagung der Deutschen Gesellschaft für Soziale Arbeit e.V., Frankfurt, Germany, 23-24 March 2012.

Treiber, M., Grießmeier N. \& Heider H. (2015). Ethnologie und Soziale Arbeit. Fremde Disziplinen, gemeinsame Fragen? Opladen: Budrich UniPress.

Wendt ,W. R. (1995). Geschichte der Sozialen Arbeit. Stuttgart: Lucius \& Lucius. Wolf, E. (1964). Anthropology. New Jersey: Prentice-Hall.

Wolf, E. (1982). Europe and the People Without History. California: University of California Press. 